\title{
Sports crimes: issues of systematic approach, criminalization and qualifications
}

\author{
Oleg Alexandrovich Dizer ${ }^{*}$, Irina Gennadievna Bavsun ${ }^{2}$, Andrey Viktorovich Zarubin ${ }^{3}$, \\ Vladimir Nikolaevich Safonov ${ }^{4}$, and Georgy Yurievich Sokolsky ${ }^{5}$ \\ ${ }^{1}$ Omsk Academy of the Ministry of Internal Affairs of Russia, Research Department, Omsk, Russia \\ ${ }^{2}$ North-West Branch of the Federal State Budgetary Educational Institution of Higher Education \\ "Russian State University of Justice", Department of State and Legal Disciplines, St. Petersburg, \\ Russia \\ ${ }^{3}$ St. Petersburg Law Institute (branch) of the University of the Prosecutor's Office of the Russian \\ Federation, Department of Criminal Law, Criminology and Criminal Executive Law, St. Petersburg, \\ Russia \\ ${ }^{4}$ North-West Branch of the Federal State Budgetary Educational Institution of Higher Education \\ "Russian State University of Justice", Department of Criminal Law, St. Petersburg, Russia \\ ${ }^{5}$ Leningrad State University named after A.S. Pushkin, Department of Criminal Law and Procedure, \\ St. Petersburg, Russia
}

\begin{abstract}
The study prerequisites are the fragmentation in the current criminal legislation of criminal law standards protecting the field of sports, as well as the issues of criminalization of acts in sports and the qualification of sports crimes. The study aims to solve the issues of systematization of regulatory provisions, the object of which is social relations in sports, taking into account the characteristics of the generic and specific objects, the degree of encroachment danger. The methods included the dialectical method, abstraction, analysis, synthesis, deduction, formal legal method, method of comparative jurisprudence. The results and novelty of the study reside in the conclusions about the advisability of identifying a separate specific object of criminal law protection (social relations in sports), which would systematize related and close acts not only in professional sports but also at all levels of official sports competitions. In this context, the issues of criminalization and qualifications of causing harm to life and health of an individual in violation of the sport rules, exerting unlawful influence on the result of an official sports competition, actions provided for in Art. 230.1 and 230.2 of the Criminal Code of the Russian Federation, as well as the synchronization of the subject of the latter with the subject of Art. 234 of the Criminal Code of the Russian Federation. Based on the foregoing, the recommendation of isolating a separate chapter in the Criminal Code of the Russian Federation and issuing a separate Resolution of the Plenum of the Supreme Court of the Russian Federation on crimes in sports is substantiated. Such measures will be able to optimize the criminal law protection of such an important sphere of public life as sports. In addition, this will make it possible to bring the quality of domestic criminal legislation and sports legislation to the international level and significantly increase the prestige of the Russian Federation.
\end{abstract}

\footnotetext{
*Corresponding author: dizer77@mail.ru
} 
Keywords: crimes in sports, systematic approach, criminalization, qualification

\section{Introduction}

Today sport is the most extensive area of society. Having arisen in primitive society in the form of rituals and customs, it actively developed in the ancient world, as evidenced by the ancient Olympic Games in Ancient Greece.

At this stage of sports development, which in the modern sense dates back to the middle of the 19th century, sport as a phenomenon occurs in almost every country.

This is explained by the positive properties of sport for society. In particular, it is the strengthening of human health, the prevention of drug addiction, alcoholism, smoking, the entertainment of sports events, etc.

However, speaking about sports, there is often the reverse side of the coin. It is expressed in socially dangerous acts in the studied area.

It is known that the priorities of criminal law protection are reflected in the systemic arrangement of the legal norms, which, in turn, is determined by the importance of the object of criminal law protection.

The principle of the systematic approach to the law and criminal law, in particular, is the most important prerequisite for its effectiveness.

\section{Methods}

It is considered to be appropriate to mention the following statement of Veklenko and Sokolov as one of the methodologically important directions of this study, "The issues of systematization and streamlining for applying in practice the current Russian legislation, reliance on the principle of consistency in law enforcement practice and lawmaking are very topical in modern domestic jurisprudence" [1].

The doctrine of criminal law testifies to different classification approaches to crimes, one way or another related to sports.

The most common approach is that crimes in sports can be classified into three main categories:

1) Crimes against life and health committed in the course of sports competitions and training; 2) bribery of participants and organizers of official sports competitions; 3) illicit trafficking in potent substances (including seduction and use of prohibited substances and methods in sports against an athlete) [2-4].

Although, there are other approaches to the classification of crimes related to sports.

In particular, the approach of Fedik and Shcherbakov, who see the system of crimes related to sports as different, highlighting "two groups of crimes that embrace the sphere of sports":

1. Deeds related to sports directly, i.e. acts that are inside the "corporation" and during sports events and competitions.

2. Acts related to sports, i.e. acts committed against the background of sports events or in connection with their holding (cases of hooliganism, riots, vandalism, injury to the health of varying severity, murder, illegal circulation of weapons, drugs, crimes of "professional" football fan groups, etc.) [5].

The authors find an approach similar to the latter in foreign sources regarding the results of research on the subject of interest [6-9].

When considering such a vast area of public relations protected by criminal law, the issue on the systematic nature of crimes in sports arises. 
It is known that the criminal legislation of the Russian Federation, unlike some other countries of the Romano-Germanic legal family, consists exclusively of the Criminal Code of the Russian Federation.

\section{$3 \quad$ Results and discussion}

In the authors' opinion, taking into account the diversity of legal relations and norms, the issue on a unified systematization of crimes in sports, not only in the criminal law science but also in domestic criminal law, arises.

In the law enforcement sphere, in the authors' opinion, it would be reasonable to create a separate Resolution of the Plenum of the Supreme Court of the Russian Federation on the issues of crimes in sports.

This is due to the fact that public relations in sports are developing every day, the same as the legislation in this area, which regulates and, in this case, protects public relations in sports.

To systematize in a separate chapter of the Criminal Code of the Russian Federation the closest acts in sports, one should choose a specific object - public relations in sports.

The conclusions of Bavsun may serve as a vector of the criminalization process, who proposes to include in separate articles the norms protecting professional sports, to strengthen responsibility for the most dangerous criminal offenses in sports already known to the criminal law, and also to criminalize acts with long-term negative consequences, the list of which is very extensive, including sports and reputation [10].

Meanwhile, in the science of criminal law, an opinion has been expressed more than once about the criminalization of such an act as causing harm to life and health as a result of a violation of the sport rules.

Thus, Skvortsov proposes to introduce Art. 239-1 on "Violation of the Sport Event Rules" [2].

At the same time, Saraev proposes to supplement the criminal law with amendments to the norms on liability for careless death causing (Art. 109 of the Criminal Code of the Russian Federation) and serious harm to health (Art. 118 of the Criminal Code of the Russian Federation) [4].

Sokolsky comes up with a proposal to qualify socially dangerous acts against life and health in sports in accordance with the current articles of the Criminal Code of the Russian Federation [11].

Thus, the issue on the criminalization of crimes against life and health as a result of a violation of the sport rules remains open, and its solution in the systemic legal sense is multivector.

Another challenge is the bribery of participants and organizers of official sports competitions provided for in Art. 184 of the Criminal Code of the Russian Federation.

Previously, this act was generally proposed to be transferred to the framework of commercial bribery [12], crimes against public health and public morality [13]. However, according to Sokolsky [14], this act has another object of criminal law protection.

Returning to the systematization of crimes in sports, it should be noted that this socially dangerous act would find its place in a separate chapter of the Criminal Code of the Russian Federation, the specific object of which would be public relations in sports.

A separate problem is the list of potent substances for Art. 234 of the Criminal Code of the Russian Federation, half of which are anabolic steroids. Besides, three quarters of the drugs from this list are used by athletes to improve sports performance.

In this regard, questions arise about 1) the need to separate a socially dangerous act into a separate corpus delicti, which establishes criminal liability for illegal circulation of potent substances in sports; 2) the publication of a separate systematized list, which would have a 
certain synchronization with the anti-doping code. It would also be advisable to approve this list by a separate Resolution of the Government of the Russian Federation.

At the same time, this corpus delicti should be placed among other sport-related crimes.

In addition, it would include norms establishing criminal liability for inducing and using prohibited substances and methods in sports against an athlete, Art. 230.1 and 230.2 of the Criminal Code of the Russian Federation.

However, a number of researchers question their criminalization in the Criminal Code of the Russian Federation like in Art. 230 of the Criminal Code of the Russian Federation. This is due to the fact that the athlete is often interested personally in improving his/her sports results and works in close connection with the subjects of these crimes. Therefore, the likelihood that he/she will point to the latter during the investigation is extremely small, which is confirmed by zero judicial statistics [15].

Serious revision of existing and proposed norms will be required, especially in terms of synchronizing the subject of these crimes with the subject of the crime under Art. 234 of the Criminal Code of the Russian Federation because "the topic of the fight against doping has turned into a topic of tough political pressure on Russia" [16].

This is supported by the study made by Ponyatovskaya, who reasonably asserts that in the norms provided for by Articles 230.1 and 230.2 of the Criminal Code of the Russian Federation, there is no connection with objects of criminal law protection and that the basis of criminal law prohibitions on doping violations is an opportunistic criterion - social and political tension [17].

\section{Conclusion}

Thus, the allocation of a separate specific object of criminal law protection (public relations in sports) can become the starting point for a scientifically grounded intersectoral and intraindustry systematization of sports delicts, justified criminalization of acts as directions for optimizing the criminal law protection of sports.

\section{References}

1. S.V. Veklenko, A.N. Sokolov, Laws of Russ.: Experience, Analysis, Practice, 4, 84-92 (2013)

2. A.A. Skvortsov, Ugolovno-pravovaya ocenka prichineniya vreda zhizni ili zdorovyu pri zanyatiyakh sportom [Criminal legal assessment of harm to life or health during sports activities], $\mathrm{PhD}$ thesis in Law (Saratov, 2005)

3. S.V. Kuzmin, Ugolovnaya otvetstvennost za podkup uchastnikov i organizatorov professionalnykh sportivnykh sorevnovanij i zrelishhnykh kommercheskikh konkursov [Criminal liability for bribery of participants and organizers of professional sports competitions and entertainment commercial competitions], $\mathrm{PhD}$ thesis in Law (Moscow, 2002)

4. V.V. Saraev, Ugolovno-pravovaya okhrana sovremennogo professionalnogo sporta $\mathrm{V}$ Rossii [Criminal law protection of the modern professional sport in Russia], $\mathrm{PhD}$ thesis in Law (Omsk, 2007)

5. E.N. Fedik, A.D. Shcherbakov, Voprosy ugolovnoj otvetstvennosti za prichinenie vreda zhizni i zdorovyu v sporte: opyt Velikobritanii [Issues of criminal liability for harm to life and health in sports: the experience of Great Britain], in Ugolovno-pravovye i kriminologicheskie problemy protivodejstviya prestupnosti v sporte [Criminal and criminological problems of combating crime in sports], Collection of materials of the 
All-Russian research and practical platform, 31 October, 2020, Saint Petersburg, Russia, 119-127 (2020)

6. E. Dunning, Eur. J. Crim. Policy Re. 8, 141-162 (2000). https://doi.org/10.1023/A:1008773923878

7. R. Spaaij, Understanding football hooliganism: a comparison of six Western European football clubs (Vossiuspers UvA, Amsterdam, 2006)

8. A. Tsoukala, G. Pearson, P. Coenen (eds.), Legal Responses to Football Hooliganism in Europe (T.M.C. Asser Press, Hague, 2016). https://doi.org/10.1007/978-94-6265-108-1

9. A. Tsoukala, Football Hooliganism in Europe: Security and Civil Fiberties in the Balance (Palgrave Macmillan, UK, 2009). https://doi.org/10.1057/9780230594661

10. M.V. Bavsun, Bulletin of the Omsk University. Pravo Series, 1(34), 217-218 (2013).

11. G.Yu. Sokolsky, Bulletin of the Oryol State University, 4(45), 400-403 (2015)

12. Enciklopediya ugolovnogo prava. T. 1. Ponyatie ugolovnogo prava [Encyclopedia of Criminal Law. Vol. 1. The concept of criminal law] (Publishing by Professor Malinin, Saint Petersburg, 2008)

13. P.V. Tsvetkov, Prestupleniya v sfere sporta: nekotorye problemy kvalifikacii [Crimes in sports: some problems of qualification], in Ugolovnaya politika i pravoprimenitelnaya praktika [Criminal policy and law enforcement practice], Collection of materials of the VII International research and practical conference, 1-2 November, 2019, Saint Petersburg, Russia, 292-297 (2019)

14. G.Yu. Sokolsky, Leningrad Legal J. 1(59), 153-160 (2020)

15. S.V. Maksimov, Russ. J. of Legal Res. 1(14), 102-114 (2018). https://doi.org/10.17816/RJLS18355

16. V.A. Zhilkin, Russ. J. of Legal Res. 3(16), 26 (2018). https://doi.org/10.17816/RJLS18376

17. T.G. Ponyatovskaya, Union of Criminalists and Criminologists of Russ. 1, 95-101 (2019). https://doi.org/10.31085/2310-8681-2019-1-204-95-101 